\title{
KAJIAN PENERAPAN STRATEGI KOMUNIKASI AISAS TERHADAP PERANCANGAN DESAIN KOMUNIKASI VISUAL
}

\author{
Hadah Muallimah \\ Program Studi Desain Komunikasi Visual \\ Sekolah Tinggi Teknologi Bandung \\ hadah@sttbandung.ac.id
}

\begin{abstract}
Abstrak
Desain komunikasi visual merupakan ilmu bagaimana merancang sebuah karya visual yang mengedepankan proses komunikasi terhadap target audience. Komunikasi sangat penting bagi setiap manusia. Dalam perancangan karya DKV, strategi komunikasi sangat penting diperhatikan agar pesan yang ingin disampaikan melalui karya dapat terkomunikasikan dengan baik kepada target audience. Tujuan dari penelitian ini yaitu memberikan pemahaman bagaimana menerapkan strategi komunikasi AISAS pada karya Desain Komunikasi Visual. Penelitian ini menggunakan metode penelitian yang digunakan dalam penelitian ini adalah metode penelitian kualitatif deskriptif. Objek penelitian ini adalah model Design Thinking, strategi komunikasi AISAS, dan model komunikasi Harold D. Lasswell. Dari model-model tersebut dianalisa bagaimana model-model tersebut bisa saling berkesinambungan antar satu dan lainnya.

Kata Kunci : Desain, Komunikasi, AISAS, Design Thinking
\end{abstract}

\begin{abstract}
Visual communication design is a design study which concerned to learn how to do design visual artwork with communication strategy for target audience. Communication is so important for human also for visual communication artwork. Communication strategy noticed as important thing to deliver a message trough visual communication design artwork to target audience. So, the message can deliver as well to target audience. This research have a purpose to be study reference about how to apply AISAS to Visual communication design artwork. Use research methode descriptive qualitative, have research object design thinking model, AISAS, and Harold D. Lasswell communication model. The models above need some analyze how the models have a connection each other. Keyword : Design, Communication, AISAS, Design Thinking
\end{abstract}

\section{PENDAHULUAN}

Komunikasi merupakan aspek kehidupan yang sangat penting bagi setiap manusia, karena manusia hidup berdampingan dan saling membutuhkan satu dan lainnya. Banyak faktor yang harus diperhatikan agar komunikasi antar sesama manusia dapat terjalin dengan baik. Komunikasi adalah proses penyampaian pesan dari seseorang kepada orang yang lain dengan tujuan memperngaruhi pengetahuan dan perilaku seseorang [1]

Bentuk dari komunikasi bukan hanya berupa verbal, akan tetapi komunikasi juga dapat terjalin dengan visual. Komunikasi visual bisa berupa teks dan gambar. Pada zaman pra-sejarah manusia telah mempraktekan bagaimana berkomunikasi dengan cara visual. Lukisan-lukisan yang ditemukan dalam gua sejarah merupakan permulaan manusia menerapkan komunikasi secara visual kepada manusia yang lainnya yang kemudian berkembang lebih maju lagi dengan bentuk komunikasi visual yang lain seperti hieroglyphics, tulisan, prasasti dan buku [2]. Oleh karena visual adalah salah satu bentuk dasar dalam proses berkomunikasi, maka terbentuklah ilmu Desain Komunikasi Visual untuk mempelajarinya.

Desain Komunikasi Visual adalah ilmu yang menerapkan proses penciptaan karya desain visual dengan mengedepankan komunikasi sebagai salah satu bagian penting dari konsep perancangan. Sebagai ilmu terapan, Desain komunikasi visual bukan hanya ilmu terapan dari ilmu seni rupa, akan tetapi sebagai ilmu yang juga menerapkan ilmu komunikasi, karena karya desain komunikasi visual adalah karya visual bukan hanya mementingkan aspek kreatifitas tapi juga yang harus bisa berkomunikasi secara efektif terhadap target audience.

Desain Komunikasi Visual menurut Sumbo Tinarbuko dipahami sebagai salah satu upaya pemecahan masalah dalam komunikasi atau komunikasi visual. Keberadaannya diabdikan untuk menghasilkan desain yang paling baru di antara desain yang terbaru [3]. Banyak hal yang harus diperhatikan agar karya desain komunikasi visual dapat memecahkan masalah dalam berkomunikasi dengan baik kepada target audience. Salah satu yang harus diperhatikan dalam aspek komunikasi adalah strategi komunikasi.

Berdasarkan tujuan awal daripada penelitian ini adalah untuk memberikan pemahaman bagaimana menerapkan strategi komunikasi AISAS terhadap karya Desain Komunikasi Visual. Oleh karena itu, salah satu strategi komunikasi yang akan dibahas pada penelitian ini adalah Strategi Komunikasi AISAS dimana AISAS sendiri merumpakan singkatan dari Attention, Interest, Seach, Action dan Share.

Dalam proses perancangan karya desain, hal yang paling utama yang harus diperhatikan adalah metode perancangan. Desain komunikasi visual memiliki berbagai metode perancangan, salah satunya adalah metode Design Thinking. Metode perancangan Design Thinking ini akan menjadi acuan proses penelitian untuk menentukan cara menerapkan AISAS terhadap karya Desain Komunikasi Visual. 


\section{LANDASAN TEORI}

\section{Komunikasi}

Komunikasi (Communication) adalah sebuah proses sistemis di mana orang dapat beriteraksi melalui symbol untuk menciptakan atau menafsirkan makna [4].

Dari definisi diatas, dapat diuraikan bagaimana komunikasi itu didefinisikan sebagai proses dan sebagai sistemis. Komunikasi merupakan proses, artinya komunikasi berlangsung dan terus bergerak, bergerak semakin maju dan berubah dengan terus menerus. Sulit mengatakan kapan komunikasi dimulai dan berhenti karena apa yang terjadi sebelum berbicara dengan seseorang bias mempengaruhi interaksi, dan apa yang muncul di dalam sebua pertemuan tertentu bias berkelanjutan di masa yang akan datang [4].

Selanjutnya, komunikasi didefinisikan sistemis yang berarti bahwa komunikasi terjadi dalam suatu sistem pada bagian yang saling berhubungan mempengaruhi satu sama lain [4]. Definisi mengenai komunikasi juga menekankan peran serta symbol yang mencangkup Bahasa dan perilaku nonverbal, serta seni dan music. Sesuatu yang abstrak menandakan sesuatu yang lain bisa menjadi symbol [4].

Komunikasi ada yang bersifat verbal dan non verbal. Komunikasi verbal adalah komunikasi yang bersifat lisan atau komunikasi dengan menggunakan kata-kata (lisan) maupun tulisan. Melalui kata-kata, dapat mengungkapkan perasaan, emosi, pemikiran, gagasan, atau maksud, menyampaikan fakta, data, dan informasi serta menjelaskannya dengan saling bertukar perasaan dan pemikiran [5].

Komunikasi nonverbal identik dengan komunikasi tanpa menggunakan kata-kata atau lebih menekankan terhadap pemaknaan symbol-simbol yang berlaku dalam social masyarakat. [5]

Komunikasi memiliki berbagai macam model, salah satu model komunikasi adalah model komunikasi Harold D. Lasswell. Paradigma Lasswell menunjukan bahwa komunikasi meliputi lima unsur sebagai jawaban dari pertanyaan yang diajukan, yaitu: Komunikator (siapa yang mengatakan?), Pesan (mengatakan apa?), Media ( melalui saluran/channel/media apa?), Komunikan (Kepada siapa?), Efek (dengan dampak/efek apa?) [6].

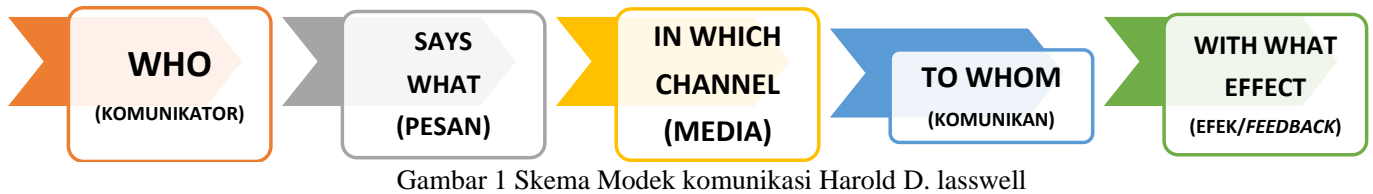

Berdasarkan paradigma Laswell tersebut, secara sederhana proses komunikasi adalah pihak komunikator membentuk pesan (encode) dan penyampaiannya melalui suatu saluran tertentu kepada pihak penerima yang menimbulkan efek tertentu. Dalam hal ini yang dimaksud dengan saluran tertentu adalah berupa penyampaian informasi atau pesan yang disampaikan oleh komunikator kepada komunikannya melalui media komunikasi [6].

\section{Strategi Komunikasi AISAS}

AISAS merupakan salah satu strategi atau model komunikasi dengan 5 (lime) elemen yaitu Attention, Interest, Search, Action dan Share. AISAS adalah model yang dirancang untuk melihat perubahan perilaku yang terjadi khususnya terkait latar belakang kemajuan teknologi internet [7].

AISAS merupakan model baru yang sebelumnya lebih dikenal dengan AIDA. AIDA singkatan dari Awareness Interest - Desire - Action merupakan model yang dicetuskan oleh Roland Hall seorang American Economist di tahun 1920. Model ini menggambarkan proses psikologis seseorang dalam membuat keputusan membeli sesuatu [8]. Model ini pada akhirnya berkembang hingga muncul dalam bentuk-bentuk lain, di antaranya adalah AIDMA (Attention, Interest, Desire, Memory, Action), yang lebih terkonsentrasi pada model comsumption behavior dalam dunia broadcasting [9].

Pada akhirnya, saat ini muncul AISAS (Attention, Interest, Search, Action, Share), yaitu suatu model consumption behavior yang digagas oleh Dentsu pada tahun 2004 [9]. Model AISAS dikembangkan oleh agen periklanan asal jepang yang pernah menjadi agen periklanan terbesar di dunia pada tahun 1974 versi majalah Advertising Age, yaitu Dentsu yang berlokasi di Tokyo Jepang. Model AISAS dinilai lebih relevan dengan era digital yang sedang berkembang saat ini [8]. 


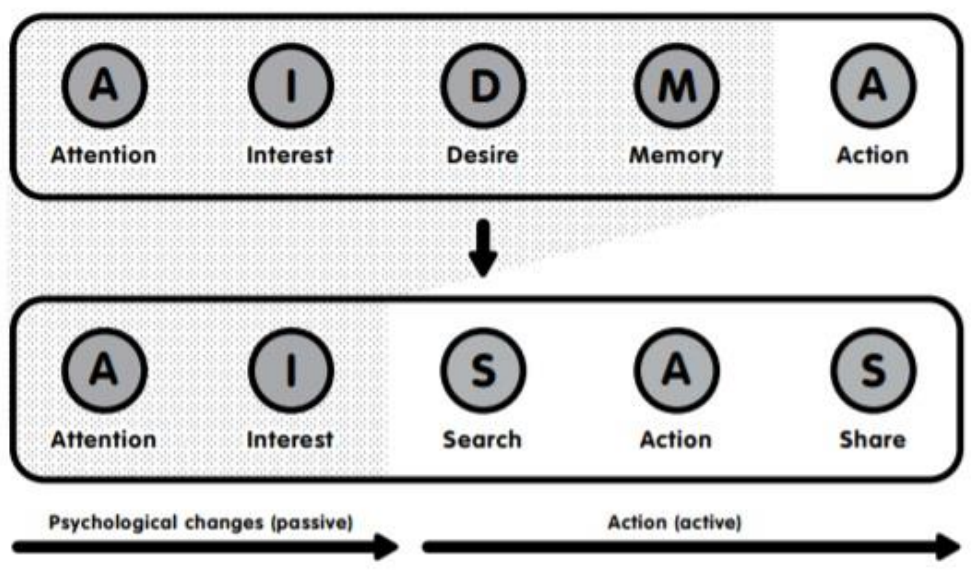

(The Dentsu Way, 2011)

Gambar 2 : Perubahan Model AIDMA ke AISAS

Sumber : www.taupasar.com, diakses pada 03 November 2021, pukul 14.42 WIB

Model ini muncul setelah adanya perkembangan internet yang sangat pesat di dunia global. AISAS lebih terkonsentrasi pada bagaimana konsumsi sebuah barang dan jasa ini dilakukan, salah satunya atas peran besar internet. AISAS dikembangkan untuk menilik tingkah laku berdasarkan pemahaman bahwa internet menjadi besar, dan bahwa konsumen saat ini memiliki akses pada lingkungan dimana mereka mendapatkan dan mengirimkan infomasi [9].

Berikut uraian mengenai AISAS dalam Virginia dan Wijaya, L (2020) [10]:

a. Awareness : Tahap dimana konsumen aware (sadar) terhadap suatu merek. Pada tahap ini konsumen hanya sekedar tau terhadap suatu merek, tanpa adanya keinginan untuk tahu lebih dalm terhadap merek tersebut.

b. Interest : Setelah tertarik terhadap merek tersebut, ada dua kemungkinan yang terjadi terhadap seorang konsumen. Pertama, konsumen tersebut tertarik dan ingin mencari tau tentang merek tersebut. Kedua, konsumen merasa tidak tertarik dan hanya mengetahui mereknya (berhenti pada tahap Awareness).

c. Search : Inilah letak perbedaan antara AISAS dan AIDA. Pada funnel AISAS ini konsumen akan mencari pengetahuan tentang produk yang membuat mereka tertarik. Kemajuan teknologilah yang membuat tahap Search ini ada. Mencari review produk sangat mudah saat ini, kelebihan dan kekurangan produk, hingga dimana tempat membeli produk tersebut.

d. Action : Setelah mendapat informasi yang cukup, itulah saat dimana konsumen membuat sebuah keputusan untuk membeli atau tidak membeli produk tersebut. Saat memutuskan untuk membelinya, maka saat itulah konsumen sudah berada dalam tahap Action.

e. Share : Tahap ini juga merupakan tahap yang merupakan tahap yang muncul seiring dengan perkembangan teknologi saat ini. Perilaku para pembeli produk tidak hanya berhenti saat membeli saja. Jika konsumen mengalami kepuasan maka hal tersebut akan mereka salurkan pada media sosialnya. Begitupula jika konsumen mengalami kekecewaan terhadap suatu produk, maka akan menghasilkan review yang buruk pula. Jejak-jejak review dari produk inilah yang akan berputrar kembali menjadi marketing funnel yang baru untuk orang lain.

3. Desain Komunikasi Visual

Desain komunikasi visual, menurut Sumbo Tinarbuko dipahami sebagai salah satu upaya pemecahan masalah komunikasi, atau komunikasu visual. Keberadaannya diabsikan untuk menghasilkan suatu desain yang paling baru di antara desain yang terbaru (Tinarbuko, 1998:66). Dalam konteks ini, penekanannya lebih menitikberatkan pada upaya pemecaham masalah komunikasi visual dengan mengedepankan unsur novelties (kebaruan) sebagai panglima perang [3].

Kusrianto (2006: 2) mendefinisikan Desain Komunikasi Visual adalah suatu disiplin ilmu yang bertujuan mempelajari konsep-konsep komunikasi serta ungkapan kreatif melalui berbagai media untuk menyampaikan pesan dan gagasan secara visual dengan mengelola elemen-elemen grafis yang berupa bentuk dan gambar, tatanan huruf, serta komposisi earna, serta layout (tataletak atau perwajahan). Dengan demikian gagasan bisa diterima oleh orang atau kelompok yang menjadi sasaran penerima pesan [11]. 
Sebagai ilmu yang mempelajari konsep komunikasi visual, maka keberadaan desain komunikasi visual mengahdirkan ungkapan daya kreatif yang diaplikasikan dalam berbagai media komunikasi visual. Kerja kreatif yang dijalankan para desainer komunikasi visual senantiasa mengolah beberapa elemen desain grafis. [3]

Desain Komunikasi Visual sebagai salah satu bagian dari seni terap mengajarkan perihal erencanaan dan perancangan berbagai bentuk informasi komunikasi visual. Perjalanan kreatifnya diawali dengan menemukan permasalahan desain komunikasi visual. Dilanjutkan dengan proses mencari data verbal dan visual. Kemudian menyusun konsep kreatif yang berlandaskan pada karakteristik sasaran [3].

Desain komunikasi visual, atau popular dengan sebutan dekave, digunakan untuk memperbaharui atau memperluas jangkauan cakupan ilmu dan wilayah kerja kreatif desain grafis. Pendeknya, konsentrasi utama desain komunikasi visual adalah desain grafis plus. Karena desain komunikasi visual adalah desain grafis plus, maka dalam kesehariannya tampilan desain komunikasi visual meliputi dua unsur utama, yakni unsur verbal (tulisan) dan unsur visual (gambar tangan, fotografi, atau image hasil olahan komputer grafis) [3].

\section{Metode Perancangan Design Thinking}

Metode perancangan design thinking adalah salah satu metode yang diterapkan dalam proses perancangan desain komunikasi visual. Design Thinking dimulai dengan sebuah perbedaan - sebuah percobaan yang dilakukan untuk mengembangkan hasil dari sebuah pilihan yang dianggap lebih baik daripada mempersempit sebuah pilihan. Artinya, design thinking ini digunakan untuk melampaui perubahan dan mencari kesempatan dalam berinovasi. Design Thinking fokus dalam mempertanyakan pertanyaan yang tepat sasaran, asumsi yang menantang, menghasilkan kemungkinan-kemungkinan dan belajar melalui tahapan proses pembuatan prototype yang berulang-ulang. Menggunakan penelitian ilmiah dalam ranah sosial dan pertanyaan yang kontekstual, design thinkers belajar bagaimana cara mengobservasi, wawancara, dan mengembangkan kedalaman empati yang menjadi dasar dalam pemecahan masalah pada manusia [12].

Design Thinking merupakan metode kolaborasi mengumpulkan banyak ide dari disiplin ilmu untuk memperoleh sebuh solusi. Design Thinking tidak hanya berfokus pada pengalaman pengguna (user). Design Thinking digunakan untuk mencari solusi yang paling efektif dan efisien untuk memecahkan suatu masalah yang kompleks [13].

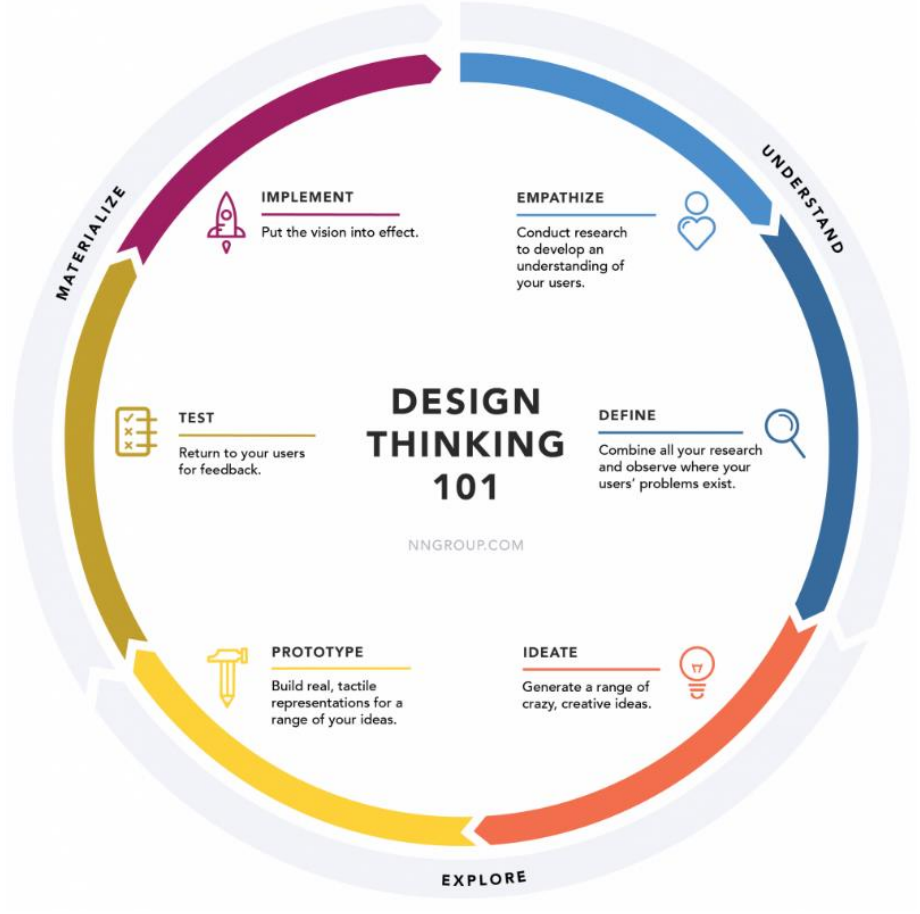

Gambar 3 Bagan Proses Design Thinking

Sumber : www.vgi.digital, diakses pada 22 November 2021, pukul 11.28 WIB

Berikut uraian mengenai design thinking yang terbagi menjadi 5 tahap (Stanford d.school) dalam Sari, dkk. (2020) [13] ;

a. Emphatize (Empati)

Emphatize (Empati) merupakan inti proses dikarenakan permasalahan yang timbul harus dapat diselesaikan dengan cara berpusat kepada manusia, metode ini berupaya untuk memahami permasalahan yang dialami pengguna agar kita dapat merasakan dan mencari solusi untuk permasalahan tersebut. Dalam metode ini ada beberapa yang harus dilakukan yaitu wawancara, observasi serta menggabungkan antara observasi dan wawancara. 


\section{b. Define (Penetapan)}

Define merupakan cara menganalisis dan memahami hasil yang telah dilakukan pada proses Emphatize dengan tujuan untuk menentukan pernyataan masalah sebagai point of view atau perhatian utama penelitian.

c. Ideate (Ide)

Ideate merupakan proses transisi dari rumusan masalah menuju penyelesaian masalah. Adapun dalam proses Ideate ini akan berkonsentrasi untuk menghasilkan gagasan atau ide sebagai landasan dalam membuat prototype rancangan yang akan dibuat.

\section{d. Prototype}

Prototype dikenal sebagai rancangan awal suatu produk yang akan dibuat untuk mendeteksi kesalahan sejak dini dan memperoleh berbagai kemungkinan baru. Dalam penerapannya, rancangan yang dibuat akan diuji coba kepada pengguna untuk memperoleh respon dan feedback untuk menyempurnakan rancangan.

\section{e. Test (Uji Coba)}

Test atau pengujian dilakukan untuk mengumpulakn berbagai feedback pengguna dari berbagai rancangan akhir yang telah dirumuskan dalam proses prototype sebelumnya. Proses ini merupakan tahap akhir namun bersifat life cycle sehingga memungkinkan perulangan dan kembali pada tahap perancangan sebelumnya apabila terdapat kesalahan

Selain 5 tahap design thinking tersebut, berdasarkan bagan proses tahapan di atas, terdapat satu tahapan lagi, yaitu tahap implementasi. Tahap implementasi ini merupakan tahap yang lebih serius. Setelah melewati dua tahap user test diatas (Prototype dan Test), produk desain seharusnya sudah dalam kondisi high fidelity yang matang dan siap diluncurkan [14].

\section{PEMBAHASAN}

Berdasarkan hasil analisa yang dilakukan terhadap model metode perancangan Design Thinking, strategi komunikasi AISAS dan model komunikasi Harold D. Lasswell, berikut pembahasan rincian bagaimana model-model tersebut dapat berkesinambungan satu dengan yang lainnya dan menghasilkan hasil karya desain komunikasi visual yang efektif untuk target audience.

Hal yang dilakukan pertama kali adalah pembahasan metode design thinking yang akan menjadi acuan penelitian. Metode design thinking memiliki 5 (lima) proses yaitu Emphatize, Define, Ideate, Prototype, Test. Kemudian akan diperinci penerapan strategi komunikasi AISAS dalam setiap kategori Design Thinking.

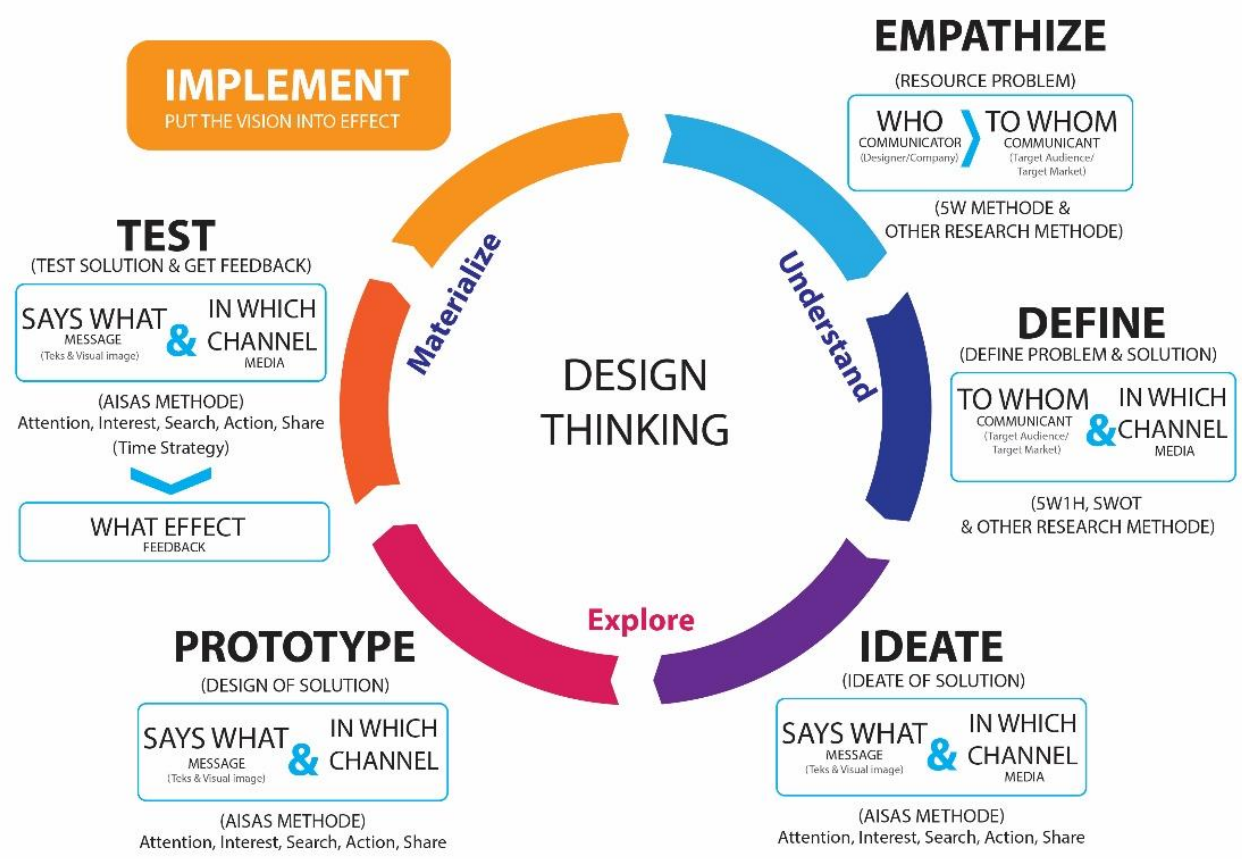

Gambar 4 Bagan Penerapan Strategi Komunikasi AISAS pada Metode Design Thinking

Berdasarkan bagan di atas, yang terdapat model komunikasi Harold D. Lasswell yang terdiri dari komunikator, pesan, media pesan, komunikan dan feedback, terdapat juga Strategi Komunikasi AISAS yaitu Attention, interest, search, action, 
share, di mana kesemuanya ditempatkan dan disesuaikan pada masing-masing kategori design thinking. Berikut rincian pembahasannya :

1. Pada kategori design thinking empathize, terdapat who (komunikator) dan to whom (komunikan), yaitu bagaimana desainer/peneliti sebagai komunikator meneliti permasalahan yang terjadi pada komunikan atau Target Audience, sehingga desainer sebagai peneliti dapat berempati atau merasakan masalah yang dialami Target Audience. Terdapat berbagai cara untuk bisa memperoleh hasil penelitian dari permasalahan, yaitu dapat diperoleh dengan Teknik pengumpulan data seperti observasi, wawancara, kuesioner, studi literatur. Juga dapat diperoleh dengan metode 5W1H (what, who, where, when, why, how) dan atau SWOT (strength, weakness, opportunity, threat). Hasil penelitian juga dapat diperloeh dengan metode penelitian lainnya. Dalam empathize ini juga, desainer/peneliti harus berusaha mengenal target audience secara mendalam dengan merinci segmentasi dari segi geografis, demografis, psikografis dan behaviour. Desainer/peneliti juga harus meneliti consumer journey. Dengan merinci segmentasi dan consumer journey, desainer/peneliti akan dapat mengenal seperti apa target audience dari karya desain yang akan dibuat.

2. Pada kategori design thinking define, terdapat to whom (komunikan) dan in which channel (Media), yaitu bagaimana desainer atau peneliti dapat menyimpulkan permasalahan yang terjadi dan dapat menentukan solusi permasalahan. Dalam tahap ini desainer sebagai peneliti mulai menentukan media apa yang akan dijadikan sebuah karya desain komunikasi visual yang dapat menjadi solusi yang tepat guna bagi Target Audience.

3. Pada kategori design thinking Ideate, terdapat Says what (pesan) dan in which channel (Media), di mana pada tahap ini desainer mulai menentukan pesan yang ingin disampaikan pada Target Audience baik berupa gagasan verbal maupun gagasan visual, dan juga melalui media apa pesan tersebut ingin disampaikan. Metode penentuan pesan dan media inilah yang akan menggunakan metode AISAS sebagai salah satu acuannya. Metode AISAS ini sangat berkaitan dengan bagaimana proses manusia dalam menerima suatu informasi.

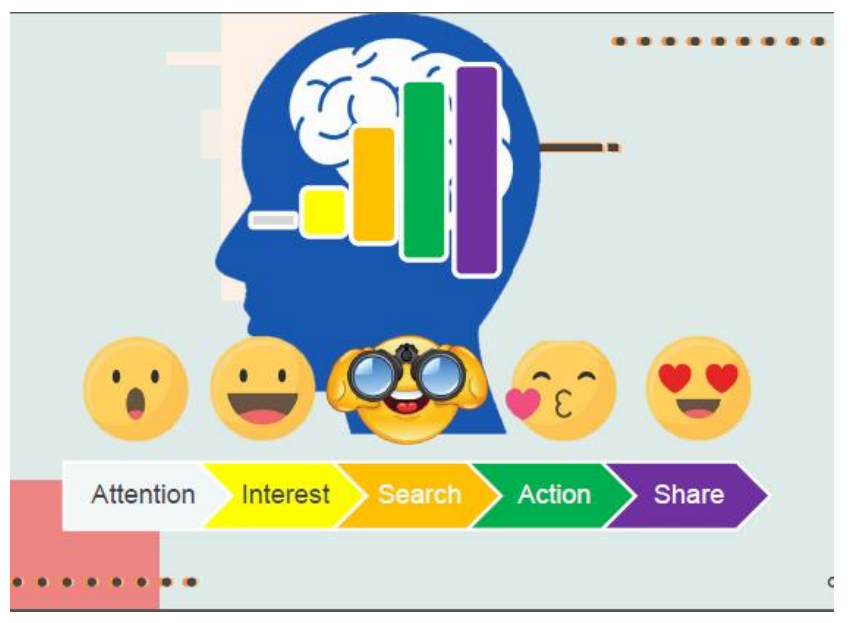

Gambar 5 Proses masuknya informasi pada otak manusia dikaitkan dengan strategi komunikasi AISAS 1

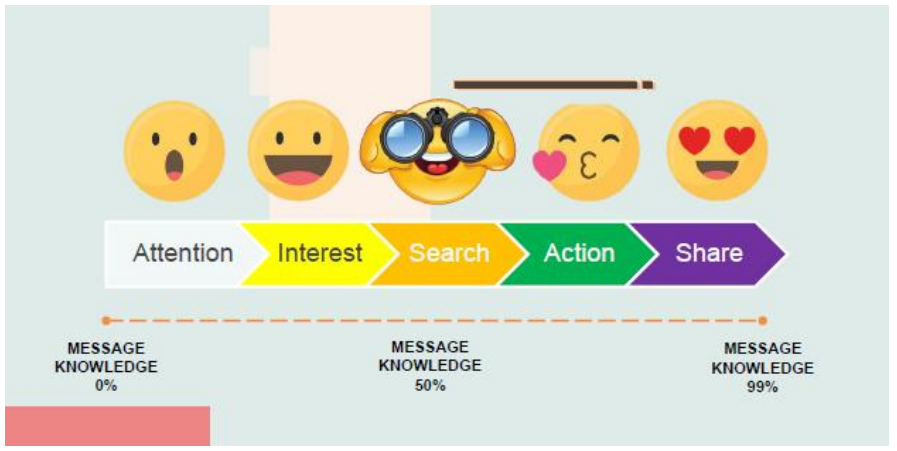

Gambar 6 Proses masuknya informasi pada otak manusia dikaitkan dengan strategi komunikasi AISAS 2 
Berikut rincian penjelasannya :

1. Dalam Menentukan pesan, penting untuk mengetahui segmentasi, terutama dari psikografis dan behaviour. Desainer sebagai peneliti harus bisa mengetahui pesan yang bagaimana yang sesuai dengan psikografis dan behaviour target audience. Namun menilik dari segi Geografis dan demografis pun tidak kalan penting. Berikut cara menentukan pesan dengan metode AISAS, yaitu dengan tahapan sebagai berikut :

a. Attention : berdasarkan makna attention yaitu perhatian. Artinya desainer harus dapat menciptakan pesan yang memberi perhatian pada target audience terhadap informasi yang ingin disampaikan. Dengan kata lain, attention ini merupakan cara memperkenalkan pesan yang ingin disampaikan. Biasanya hanya berupa tagline atau copywriting. Jika dikaitkan dengan karya desain komunikasi visual maka isi informasi yang akan diperkenalkan dapat berupa promosi sebuah produk, memperkenalkan sebuah brand/produk, dasar sebuah isu sosial untuk perancangan kampanye sosial, atau informasi lainnya. Biasanya jika dikaitkan dengan karya desain komunikasi visual, maka gagasan verbal pada pesan attention ini tidak lebih banyak daripada gagasan visual. Bahkan terkadang tidak ada gagasan verbal, hanya gagasan visual. Pesan yang disampaikan juga tidak langsung to the point, akan tetapi dibuat agar membuat penasaran target audience. Cara mudah dalam mencari referensi terkait pesan dari attention ini, salah satunya dengan memperhatikan video iklan pada media televisi maupun media sosial salah satunya youtube. Biasanya pesan attention akan teridentifikasi pada detik-detik pertama. Jika sebuah video iklan memiliki durasi 30 detik, maka dalam 2-3 detik pertama dapat teridentifikasi pesan attention. Pesan pada attention ini harus bisa menarik perhatian target audience dalam sekejap mata ditengah-tengah berbagai aktifitas target audience. Bagaimana caranya agar target audience secara otomatis ingin melihat pesan apa yang ingin disampaikan, sehingga informasi dapat tersampaikan dengan efektif.

b. Interest : berdasarkan makna interest yaitu menarik. Artinya setelah berhasil menarik perhatian dari pesan attention, maka mulai dengan level penerimaan informasi berikutnya, yaitu menarik minat target audience untuk mengetahui lebih lanjut mengenai informasi yang akan disampaikan. Bagaimana target audience dapat secara otomatis berminat, ingin mengetahui informasi yang akan disampaikan. Sama dengan attention, biasanya gagasan verbal hanya berupa tagline atau copywriting. Kembali mengidentifikasi contoh dari video iklan pada media televisi maupun media sosial salah satunya youtube. Jika sebuah video iklan memiliki durasi 30 detik, maka dalam detik 4-6 dapat teridentifikasi pesan interest. Biasanya jenis pesannya sudah mulai menjelaskan informasi yang disampaikan namun masih belum banyak informasi. Biasanya dijelaskan dengan satu kalimat saja. Namun, dibandingkan gagasan verbal pada attention yang cenderung sedikit bahkan tidak ada, gagasan verbal pada interest ini hampir menjelaskan secara to the point pesan yang ingin disampaikan, tetapi tetap harus diperhatikan tata bahasanya agar tetap bisa membuat penasaran target audience.

c. Search : berdasarkan makna search yaitu mencari. Artinya setelah berhasil menarik perhatian, maka desainer harus menyuguhkan informasi yang sangat jelas untuk dapat dikertahui target audience. Pada tahap ini Target Audience harus dimanjakan dengan suguhan informasi yang detail dan jelas. Jika dalam sebuah poster atau media lain yang tidak bisa menampilkan banyak informasi, maka dalam media tersebut Target Audience harus diarahkan kepada tautan atau tempat dimana informasi detail tersebut berada. Misalnya, dalam poster media sosial Instagram, target audience diarahkan pada tautan sebuah situs yang menampilkan informasi yang sangat lengkap mengenai informasi yang disampaikan. Kembali lagi mengidentifikasi contoh dari video iklan pada media televisi maupun media sosial salah satunya youtube. Jika sebuah video iklan memiliki durasi 30 detik, maka dalam detik 7-22 dapat teridentifikasi pesan search. Porsi durasi yang dipakai search ini memang biasanya mendominasi video iklan tersebut agar target audience dapat menerima informasi dengan sejelas mungkin.

d. Action : berdasarkan makna action yaitu aksi. Artinya setelah target audience disuguhkan dengan informasi yang lengkap, maka dalam action ini, gagasan pesan yang dibuat harus mulai mengajak target audience untuk melakukan yang dipesankan. Jika promosi produk, maka pesan yang disampaikan harus dapat mengajak target audience untuk membeli produk tersebut dan secara otomatis target audience berkeinginan besar untuk membeli produk tersebut. Jika dengan kalimat ajakan saja tidak cukup membantu, maka bisa dengan metode lain seperti dengan menginformasikan promo produk, informasi diskon, hadiah, dsb. Jika dalam kampanye sosial, maka pesan yang disampaikan harus dapat mengajak target audience melakukan aksi sosial yang dipesankan. Dengan pesan yang disampaikan Target audience secara otomatis tergerak melakukan aksi sesuai pesan yang disampaikan. Kembali lagi mengidentifikasi contoh dari video iklan pada media televisi maupun media sosial salah satunya youtube. Jika sebuah video iklan memiliki durasi 30 detik, 
maka dalam detik beberapa detik terakhir dapat teridentifikasi pesan action. Dalam sebuah video iklan, biasanya detik-detik terakhir diakhiri dengan pesan action dan selesai.

e. Share : berdasarkan makna share yaitu berbagi. Artinya setelah target audience mau melakukan aksi pada tahap action, misi sebagi komunikator tidak sampai disini. Ada tahap lanjutan yang cukup penting, yaitu tahap di mana target audience diajak untuk mau berbagi. Jika dalam promosi produk, maka target audience diajak untuk mau merekomendasikan produknya kepada orang lain. Jika dalam kampanye sosial, maka target audience diajak untuk mau turut mengajak orang lain melakukan aksi serupa. JIka dengan kalimat ajakan tidak cukup, maka bisa juga dengan metode memberi merchandise atau hadiah. Kembali mengidentifikasi video iklan, pesan ajakan share ini dapat ditambahkan ke video iklan jika perlu. Terkadang dalam beberapa video iklan yang membutuhkan pesan share, detik-detik terakhir tidak berakhir dengan pesan action saja, tapi ditambah dengan pesan share. Pesan share ini akan sangat mudah ketika disampaikan melalui media sosial, karena sudah terdapat fitur share dalam platform media sosial.

f. Menentukan media penyampai pesan yang akan disampaikan dengan menggunakan AISAS. Dalam penentuan media ini sangat berkaitan erat dengan segmentasi dan consumer journey, yaitu mengenai apa saja media yang sekiranya akan ditemui target audience ditengah-tengah aktifitasnya. Berikut penjelasan rinciannya :

g. Dalam tahap Attention dan Interest, desainer sebagai peneliti harus bisa menentukan media yang dianggap paling sering ditemui dan menarik perhatian target audience di tengah-tengah aktifitasnya. Hal ini sangatlah berhubungan erat dengan segmentasi dan consumer journey. Ini sangat penting, sebab jika media yang dipakai jarang atau bahkan tidak pernah ditemui konsumen, komunikasi tidak akan efektif. Seperti contoh bagi segementasi lansia yang jarang atau bahkan tidak membuka media sosial, jangan diberi media Instagram, hal tersebut akan menjadikan komunikasi tidak efektif.

h. Dalam tahap Search, desainer sebagai peneliti harus bisa menentukan beberapa aspek media. Aspek pertama adalah media yang paling sering ditemui konsumen. Aspek kedua adalah media yang bisa menampung informasi yang lengkap. Aspek ketiga adalah media yang bisa menjadi perantara dalam menginformasikan media yang menampung informasi lengkap. Contoh kasus media iklan poster Instagram yang tidak bisa menampung informasi lengkap, maka dalam poster itu diberikan tautan profil Instagram atau situs internet yang dapat menampung informasi lengkap.

i. Dalam tahap Action dan Share juga sangat pengting menentukan media yang sering dipakai target audience. Namun tidak cukup sampai disitu, karena dalam tahap ini, desainer sebagai komunikator harus bisa mengajak target audience. Oleh karena itu, apabila media iklan/media promosi baik media cetak atau media digital yang digunakan tidak cukup, maka harus disertai dengan media Gimmick, yaitu media yang dapat menarik perhatian konsumen namun penggunanannya apabila sangat diperlukan saja, hanya sebagai penyempurna saja. Biasanya berupa merchandise atau stationary.

2. Pada kategori design thinking prototype, desainer mulai mendesain karya sesuai dengan gagasan verbal, gagasan visual dan media yang telah ditentukan. Dalam tahap ini sangat penting memperhatikan hirarki visual dan prinsip desain. Penting juga mengetahui presentase porsi gagasan verbal dan gagasan visual yang akan diterapkan pada setiap media yang sudah ditentukan dengan kategori AISAS.

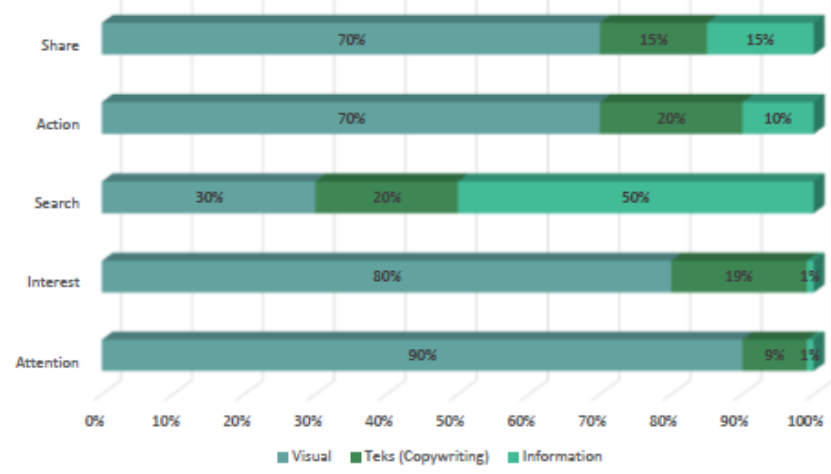


a. Pada media Attention, idealnya gagasan verbal hanya sedikit atau bahkan tidak ada. Berikan porsi terbanyak untuk gagasan visual. Dapat diberikan informasi lain namun hanya jika diperlukan.

b. Pada media Interest, porsi gagasan verbal sudah mulai lebih banyak dari tahap attention, namun porsi visual masih lebih banyak. Dapat diberikan juga informasi lain, namun juga tidak banyak.

c. Pada media search, porsi gagasan verbal terutama informasi lengkap harus lebih banyak daripada porsi visual.

d. Pada media attention dan share memiliki porsi yang hampir sama dengan attention dan interest.

3. Pada kategori design thinking test, desainer/publisher mulai menguji coba hasil desain pada target audience. Melalui metode AISAS, desainer dapat menguji coba setiap tahapannya yang idealnya dilakukan secara bertahap. Strategi penggunaan waktu sangat penting pada saat uji coba, hal ini dikarenakan komunikasi tidak akan efektif apabila semua kategori dilakukan secara bersamaan. Video iklan pun memiliki perencanaan durasi walaupun pada saat di publish dilakukan sekaligus. Desainer selaku publisher harus bisa menentukan berapa lama waktu yang dibutuhkan target audience dalam menangkap setiap informasi yang disampaikan dari setiap kategorinya. Terutama hal ini sangat berkaitan erat dengan media promosi atau media iklan. Berapa lama waktu yang dibutuhkan dalam menangkap pesan Attention, Berapa lama waktu yang dibutuhkan dalam menangkap pesan Interest, dan seterusnya. Pada tahap ini akan diperoleh hasil berupa timbal balik atau feedback dari target audience. Tahap test menjadi tahap terakhir, namun belum berakhir. Karna jika terjadi permasalahan harus kembali lagi ke tahap awal. Namun jika sudah tidak ada masalah bisa dilanjutkan ke tahap terakhir yaitu implementasi. Pada tahap ini artinya misi penyampaian pesan AISAS melalui karya desain komunikasi visual sudah selesai.

\section{KESIMPULAN}

Desain komunikasi visual merupakan ilmu bagaimana merancang sebuah karya visual yang mengedepankan proses komunikasi terhadap target audience. Komunikasi sangat penting bagi setiap manusia, karena dengan komunikasi manusia dapat berinteraksi dan bersosialisasi dengan manusia lainnya. Begitupun dalam perancangan karya DKV, strategi komunikasi sangat penting diperhatikan agar pesan yang ingin disampaikan melalui karya dapat terkomunikasikan deng an baik kepada target audience.

Tujuan dari penelitian ini yaitu memberikan pemahaman bagaimana menerapkan strategi komunikasi AISAS pada karya Desain Komunikasi Visual, maka metode penelitian yang digunakan dalam penelitian ini adalah metode penelitian kualitatif deskriptif. Objek penelitian ini adalah model Design Thinking, strategi komunikasi AISAS, dan model komunikasi Harold D. Lasswell. Dari model-model tersebut dianalisa bagaimana model-model tersebut bisa saling berkesinambungan antar satu dan lainnya.

Hasil dari kajian penerapan strategi komunikasi AISAS terhadap metode Design Thinking yaitu bahwa tahapan AISAS tidak dimulai dari tahap awal design thinking yaitu empathize. Tahapan AISAS sendiri baru mulai diimplementasikan pada tahapan Ideate, yaitu tahapan penentuan ide atau solusi dari sebuah permasalahan atau karya yang akan di design. Walaupun begitu banyak hal yang harus diperhatian. Setiap hasil dari tahapan penelitian seperti Empathize dan define harus dapat diterapkan ketika menentukan ide dan solusi.

Dengan demikian, semoga penelitian ini dapat bermanfaat bagi mahasiswa, akademisi maupun praktisi yang bergerak di bidang desain komunikasi visual dalam membuat karya agar pembuatan karya desain komunikasi visual bisa lebih terarah dan terencana

\section{REFERENSI}

[1] H. Cangara, Pengantar Ilmu Komunikasi (Edisi Kedua), Jakarta: PT. RajaGrafindo Persada, 2016.

[2] M. Etzha and P. Persada, "LANDASAN KONSEPTUAL PERENCANAAN DAN PERANCANGAN PUSAT PENDIDIKAN DESAIN KOMUNIKASI VISUAL MODERN DI YOGYAKARTA," S1 Thesis UAJY, Maret 2015.

[3] S. Tinarbuko, Perancangan dan Pengkajian Desain Komunikasi Visual, I. S. Alim, Ed., Yogyakarta: Badan Penerbit ISI Yogyakarta, 2021.

[4] W. T. Julia, Komunikasi Teori dan Praktik, Jakarta: Salemba Humanika, 2013.

[5] S. Ramadanty, "PENGGUNAAN KOMUNIKASI FATIS DALAM PENGELOLAAN HUBUNGAN TEMPAT KERJA," Jurnal Ilmu Komunikasi, vol. 5, pp. 1-118, 2014.

[6] A. H. Fahma and Nurhalimah, "ANALISIS MODEL KOMUNIKASI HAROLD DWIGHT LASWELL TERHADAP NOVEL ASMA NADIA CINTA 2 KODI," Dakwatuna: Jurnal Dakwah dan Komunikasi Islam, vol. 4, 2018.

[7] taupasar.com, "www.taupasar.com," 28 May 2020. [Online]. Available: https://www.taupasar.com/2020/05/model-aidma-aida-hingga-aisasdalam.html. [Accessed 03 September 2021].

[8] A. Muliani, "IMPLEMENTASI STRATEGI ONLINE PR TANAMERA COFFEE DALAM MENCIPTAKAN BRAND IMAGE: STUDI KASUS TERHADAP AKUN INSTAGRAM TANAMERA COFFEE," Bachelor Thesis thesis, Universitas Multimedia Nusantara., 2017. 
KREATIF(Jurnal Karya Tulis, Rupa, Eksperimental dan Inovatif)

Vol. 04 No. 01 Juni 2022

P-ISSN: 2746-4369 || E-ISSN: 2714-9978

[9] F. W. Wirawan and P. D. Hapsari, "Analisis AISAS Model terhadap product placement dalam film indonesia Studi Kasus : Brand Kuliner di Film Ada Apa Dengan CInta 2," Jurna Rekam, vol. 12, 2016.

[10] Virginia and L. S. Wijaya, "Analisis AISAS Model Terhadap "BTS Effect" Sebagai Brand Ambassador dan Influencer," Journal Komunikasi, vol. 11, 2020.

[11] E. Herliyani and J. Suryana, "DKV Sebagai Perancangan Media Promosi Jurusan Desain Komunikasi VIsual (DIII) UNDIKSHA Berbasis WEB," PRASI, vol. 10, 2015.

[12] M. Carroll, "Stretch, Dream, and Do-A 21st Century Design Thinking \& STEM Journey," Journal of Research in STEM Education, vol. 1, pp. 59-70, 2015.

[13] I. P. Sari, A. H. Kartina, A. M. Pratiwi, F. Oktariana, M. F. Nasrulloh and S. A. Zain, "Implementasi Metode Pendekatan Design Thinking dalam Pembuatan Aplikasi Happy Class Di Kampus Cibiru," Journal Pendidikan Multimedia, vol. 2, no. 1, pp. 45-55, 2020.

[14] F. Utari, "vgi.digital," [Online]. Available: https://vgi.digital/design-thinking-apa-itu-design-thinking/. [Accessed 22 November 2021]. 